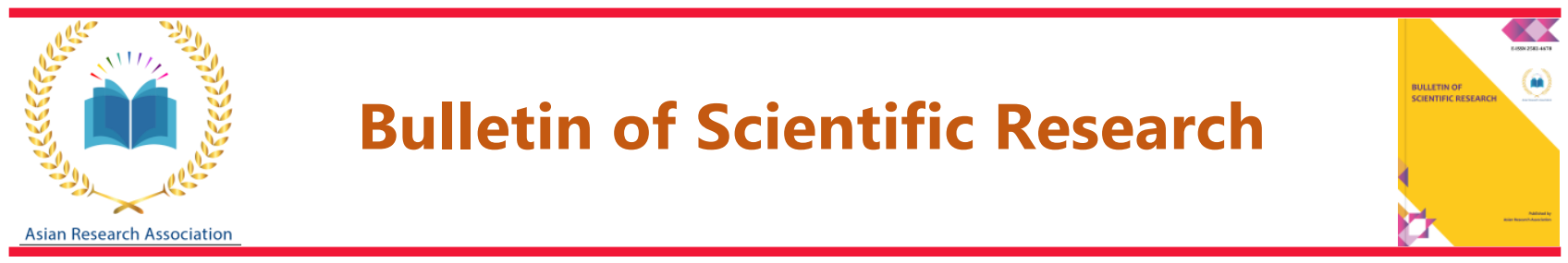

\title{
Investigation of Structures of Sintered Processed Fly Ash Materials: Resources of Industrial Wastes
}

\author{
M.K. Panigrahi a, * \\ a PG Department Materials Science, Maharaja Sriram Chandra Bhanja Deo University, Keonjhar Campus, Odisha, \\ India \\ *Corresponding author Email: muktikanta2@gmail.com \\ DOI: https://doi.org/10.54392/bsr2211
}

Received: 28-07-2021; Revised: 30-12-2021; Accepted: 01-01-2022; Published: 03-01-2022

Abstract: The aim of the work is to use industrial waste as resource materials for formulating useful product for society. Materials are prepared using Fly ash as main ingredient through sintered process via solid state route. Different materials are prepared using various sintering temperature. The crystal structural and phases are explored by XRD analysis. Mulite phase are investigated, which is indicated the insulating properties of the materials. Surface topography of the prepared materials is analyzed by FESEM characterization. EDS analysis is also done during the FESEM characterization and is assessed the various chemical compositions. Identification of different chemical groups in the processed Fly Ash is carried out by FTIR analysis. Highest electrical resistivity is estimated and is found to be $35.1 \mathrm{M} \Omega$, which indicates the very good insulating property.

Keywords: Industrial Wastes, Fly ash, XRD, Phases, Mulite, Insulator, Morphology, Resistivity

\section{Introduction}

The usage of out-of-date ceramics is more and more attractive. This is predominantly due to their availability and lower cost raw material. Fly ash (FA) is one of the Industrial wastes, which is obtained from thermal power plants. After reviewing the chemical and physical behaviour of $F A$, it creates variety of problems such as environment problem, health problem and reduces fertility of soil in the Universe [1-5]. Hence, the research communities are dedicated to endure the research on waste materials and will try to make value added materials or products to the civilization in economic way. One of the valuable products is electrical insulator [6-8].

An effort has been made in order to use fly ash, which is an available locally as raw material for preparing ceramic materials production. The ceramics are important in many applications such as refractories materials [9], cutting tools [10], thermal insulator [11], etc. The materials are usually prepared by using pressure followed by firing temperature. Amount of crystalline phases are formed during sintering process. At low sintering temperatures-based ceramics production is not indicated enhanced properties. Definitely, the performances of the ceramics are mostly estimated by the occurrence of enough amount crystallized phase. For getting this phase, sintering process/temperature of ceramics is must essential.
The process is used to develop the formation of mullite phase in the system, The mulite phase formation can be completed at 1150 to $1200{ }^{\circ} \mathrm{C}$ firing temperature (not below) [12].

The utilization of ceramic materials such as electrical insulators goes back to 1850 . Werner von Siemens [13] has used ceramics during the construction of electrical air lines. There are numerous characteristic behaviour of ceramics i.e., mechanical strength, high-power dielectric strength, and corrosion resistance. Electrical insulator can be classified on the basis of their purpose and insulation properties value $[14,15]$. In Today scenarios, there is growing demand for low cost insulator in the area of electrical engineering and caused by the importance of electric energy in modern society. It motivates too many researchers to focus on their best properties, which is essential for technological applications [16].

Prospective uses of ceramics in the field of electrical engineering, numerous applications are determined by dielectric properties. Dielectric materials having dielectric constant values are above 12 and are used in capacitors and transducers applications. Ceramic capacitors are extensively used as electronic components, which is played a very significant role in electronic sectors. In the present time, fast growing capacitor technology is mainly ceramic based materials, which is attained our requirements of 
advancement in microelectronics and communication engineering. It is envisaged that more applications of ceramic capacitors will be found in future [17].

In electrical properties point of view, Insulators have great importance in day-to-day life. It makes our life easy, harmless and shock free. Insulators are used varieties of knowingly or unknowingly purposes. Electrical pin is used in electrical poles i.e., one kind of insulator [6-8]. As like insulators, dielectrics are also very important and used not only in our day to day life but also it has high value in high technology applications such as defence [6], microwave [22, 7], capacitors [8], supercapacitors [18], microwave engineering [7], phase shifter [19], filter [20] and resonator [21] etc.

In this work, processed Fly ashes based materials are prepared through sintered process by solid state route. The materials are prepared using three different sintering temperatures i.e., $900^{\circ} \mathrm{C}, 1100$ ${ }^{\circ} \mathrm{C}$, and $1200{ }^{\circ} \mathrm{C}$, respectively. The morphological characterization with EDS analysis is done. Different phases such as quartz, Crystobalite, $\mathrm{TbO}_{2}$, and mullite of as-prepared sintered Fly ash materials has been done by X-ray diffraction analysis. Fourier transforms infrared spectroscopy (FTIR) analyses is carried out to recognize the presence of chemical groups in the asprepared materials. Electrical resistivity value is estimated.

\section{Experimental Details}

\subsection{Materials and Chemicals}

Fly ash is received from NALCO Navaratna Company, Damanjodi, Odisha. The composition of areceived Fly ash is mentioned in Table 1.

Table 1 Different constituents with percentage of asreceived NALCO fly ash

\begin{tabular}{|l|l|}
\hline \multirow{2}{*}{ Constituents with } & Used industrial waste \\
\cline { 2 - 3 } percentages & $\mathrm{Fly}$ ash \\
\hline & $\mathrm{Fe}_{2} \mathrm{O}_{3}=8.1$ \\
& $\mathrm{MgO}^{2}=1.14$ \\
& $\mathrm{Al}_{2} \mathrm{O}_{3}=24.98$ \\
& $\mathrm{SiO}_{2}=55.85$ \\
& $\mathrm{P}_{2} \mathrm{O}_{5}=0.15$ \\
& $\mathrm{SO}_{3}=1.16$ \\
& $\mathrm{~K}_{2} \mathrm{O}=0.85$ \\
& $\mathrm{CaO}=2.54$ \\
& $\mathrm{Na}_{2} \mathrm{O}=0.2$ \\
& $\mathrm{TiO}_{2}=1.75$ \\
& $\mathrm{CO}_{2}=1.56$ \\
\hline Sources & $\mathrm{NALCO}, \mathrm{BBSR}$ \\
\hline References & {$[22]$} \\
\hline
\end{tabular}

Dextrin $\left.\left(\mathrm{C}_{6} \mathrm{H}_{10} \mathrm{O}_{5}\right)_{n .} \times \mathrm{H}_{2} \mathrm{O}\right)$ is procured from Loba chemicals. Water $(6 \%)$ is needed to prepare the materials.

\subsection{Materials Preparation [22]}

Fly ash is grinded in a ball mill for $5 \mathrm{~h}$ and is sieved in 240 meshes. Then, the fly ash is dried in heating oven at $120^{\circ} \mathrm{C}$ in $2 \mathrm{~h}$ for removing moisture.

$10 \mathrm{~g}$ Fly ash (FA) i.e., $100 \% \mathrm{FA}$ is grinded in a ball mill for $5 \mathrm{~h}$. Binder is used to bind the FA particles. For this purpose, $0.05 \%$ dextrin is taken and is grinded for $1 \mathrm{~h}$. Small amounts of water is also taken and made paste. The sample is ready for making pellet. The sample is called green sample and the Corresponding pallet is called green pallet.

Pellets are prepared by universal testing machine (UTM) with pelletizer using green samples. Before preparing pallets, the assembled pelletizer are cleaned, washed, and dried. The green samples are put in the pelletizer. $10 \mathrm{MPa}$ pressure is applied to the sample contained palletizer and it is left for five minutes to form desired shaped pellet. After that, pelletizer is removed from compressed mould, which is placed in UTM machine and then the green pellet sample is removed. Green pallet thicknesses and diameter are measured and is found to be $1.1 \mathrm{~mm}$ and $10 \mathrm{~mm}$. The green pallet is ready for using sintered process.

The green pellet samples are placed in muffle furnace and bisquetted at $900{ }^{\circ} \mathrm{C}$ for $2 \mathrm{~h}$. This step is used for removing water and the process is called bisquetting. Then, the pallet is sintered at $1200{ }^{\circ} \mathrm{C}$ for $1 \mathrm{~h}$ and the process is called sintering process.

In this process, binder i.e., dextrin and intacted water is removed from the bisquetted pallet(s). The sintered pallet(s) is ready for different characterizations. The sintered pallet dimension i.e, thickness and diameter are found to be $1.09 \mathrm{~mm}$ and $10 \mathrm{~mm}$, respectively. The entire sintering process is shown schematically in Scheme 1.

\subsection{Characterization Methods}

XRD (X-ray diffraction) characterization is employed to identify the phases and Phillips PW-1710 advance wide angle $\mathrm{X}$-ray diffractometer, Phillips PW1729 X-ray generator instrument is used to perform the characterization. X-ray is generated from $\mathrm{Cu}$ metal target and CuKa radiation (wavelength, $\lambda=0.154 \mathrm{~nm}$ ) is used for their analysis. The machine is functioned at $40 \mathrm{kV}$ and $20 \mathrm{~mA}$. The pallet sample is put on a quartz sample holder. The measurement is done at room temperature. It is scanned at diffraction angle $2 \theta$ from $20^{\circ}$ to $180^{\circ}$ and scanning rate is $2 \%$ min.

Surface topography of sintered samples is analyzed by field emission scanning electron microscopy (FESEM) using (Carl Zeiss Supra 40). Formerly FESEM analysis, gold coating is performed through sputtonic technique. FESEM operating voltage is kept at $30 \mathrm{kV}$. 


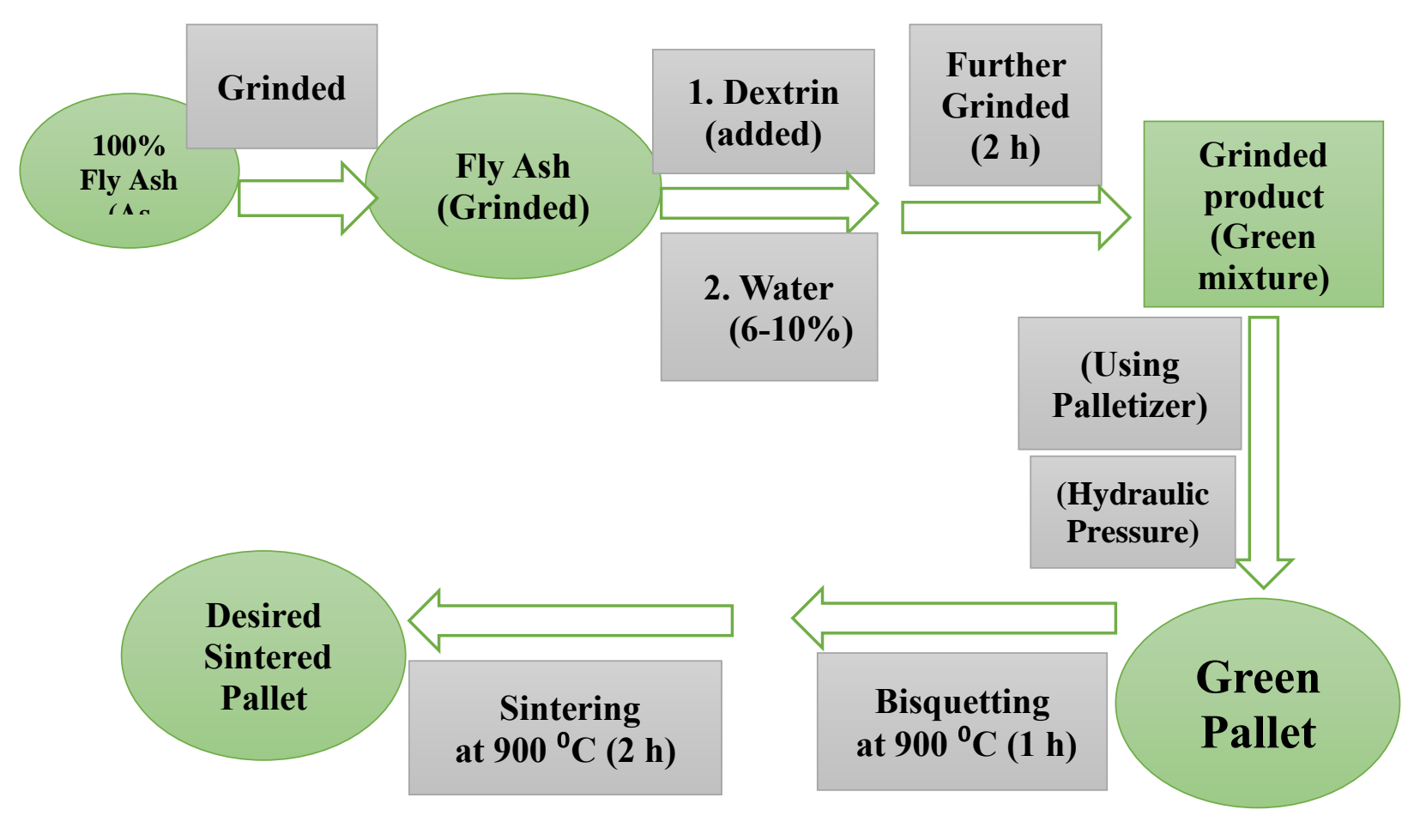

Scheme 1 The flow chart for preparation of sintered Fly ash based materials

FTIR spectra of sintered FA are recorded on a Thermo Nicolt Nexus 870 spectrophotometer. The analyses are made from $400 \mathrm{~cm}^{-1}$ to $4000 \mathrm{~cm}^{-1}$. Measurements are taken in absorbance mode. Instrument parameters are kept constant (50 scan at $4 \mathrm{~cm}^{-1}$ resolution) during the measurements. For these analyses, samples (i.e., pallet) are prepared by compression molding using a pelletizer. Potassium Bromide $(\mathrm{KBr})$ and small amounts of test samples are used to make pallet. A background spectrum is collected before doing the experiments. Then, pallet is put in a sample holder and data are collected.

For electrical measurement, sintered pellet samples are used. Resistivity measurement is one of the electrical measurements. The dielectric measurements of the sintered pellet are measured trough Multimeter. Resistivity is estimated using the expression [22]

$$
\rho=\left(\frac{R \times A}{l}\right)
$$

Here, A is the area of electrode $=\frac{\pi}{4} D^{2}\left(\mathrm{~m}^{2}\right), \mathrm{R}$ is the resistance of prepared samples $(M \Omega), \quad I$ is thickness of the sample, $\rho$ is the resistivity of the samples in $\mathrm{M} \Omega$.

\section{Results and Discussion}

FESEM images of as processed fly ash and sintered Fly ash materials are shown in Figure 1. Surface topography of as processed Fly ash is indicated Figure 1(A). Fly ash sintered materials are shown in Figure 1(B-D). It is observed from Figure Figure $1 \mathrm{~A}$ that as processed Fly Ash is irregular shape of spheres with a regular smooth surface. FA sintered at $900{ }^{\circ} \mathrm{C}$ is shown in Figure 1B. There is slightly morphological transformation occurs from irregular spherical spheres to small crystal structures in the image. Also, there is found small gaps between the crystals. Figure $1 \mathrm{C}$ is Showed FA, which is sintered at $1100{ }^{\circ} \mathrm{C}$. It indicates segregate structure with pores. FESEM image of sintered Fly ash (at $1200{ }^{\circ} \mathrm{C}$ ) is exposed in Figure 1D. It shows non-uniform segregated structure with small pores. This is formed due to the sintering reaction of FA spheres and is expected to be advantageous for higher crystallinity.

EDS analyses are done during the FESEM studies (Figure 2). The elements such as $\mathrm{O}, \mathrm{Al}, \mathrm{Si}, \mathrm{Ti}$, $\mathrm{Fe}$, and $\mathrm{K}$, are present in Fly Ash (sintered at $900^{\circ} \mathrm{C}$, Fig. 2A) except $\mathrm{Na}, \mathrm{Ca}$, and $\mathrm{Mg}$ elements. Ti element is present in trace amounts in sintered fly ash (at 900 ${ }^{\circ} \mathrm{C}$, Fig. 2A). O, Al, $\mathrm{Si}, \mathrm{Ti}, \mathrm{Fe}, \mathrm{K}, \mathrm{Na}, \mathrm{Ca}$, and $\mathrm{Mg}$ elements are occurred in the sintered Fly Ash (at 1200 ${ }^{\circ} \mathrm{C}$, Fig. 2A). Ti and $\mathrm{Mg}$ elements are present in trace amounts in the sintered Fly Ash (at $1200^{\circ} \mathrm{C}$, Fig. 2A). 
All the elements except $\mathrm{Mg}$ are shown in Fig.2B (Sintered fly ash, $1100^{\circ} \mathrm{C}$ ).

Figure 3 shows the XRD parrten of as-received Fly Ash from NALCO, Damanjodi. Different phases i.e., alumina, silica, and mulite are identified. The highest intensity phase is silica and the maximum intensity is 450 a.u., which is very small. In the XRD parrten (Fig. 3 ), a few amounts of mulite phase is recognized at different glancing angles [22]. Alumina is also presented in as received Flyash [22]. However, presence of some peaks of silica and alumina in the XRD parrten show that some of these have not formed Mullite.

Figure 4 shows the XRD parrten of processed Fly Ash, which is sintered at $900{ }^{\circ} \mathrm{C}$. Various peaks are observed in the spectrum. Table 2 indicates the crystal system and crystallographic parameters such as unit cell dimension, crystal angle, space group, space group number, and density of identified phases. The corresponding line XRD parrten of identified phase is also found in the Fig.4. The highest intense peak is found at $26^{\circ}(2 \theta)$ in the XRD parrten (Fig.4) and the phase is silica (ICSD analysis). The silica phase belongs in hexagonal crystal system. Crystallographic parameters are presented in Table 2. The other silica phase is observed at $42^{\circ}, 74^{\circ}$, and $79^{\circ}$, respectively. Other phases such as mulite and alumina may present. In addition, Table 3 contains miller indices and $d$ spacing of sintered Fly Ash (at $900^{\circ} \mathrm{C}$ ).

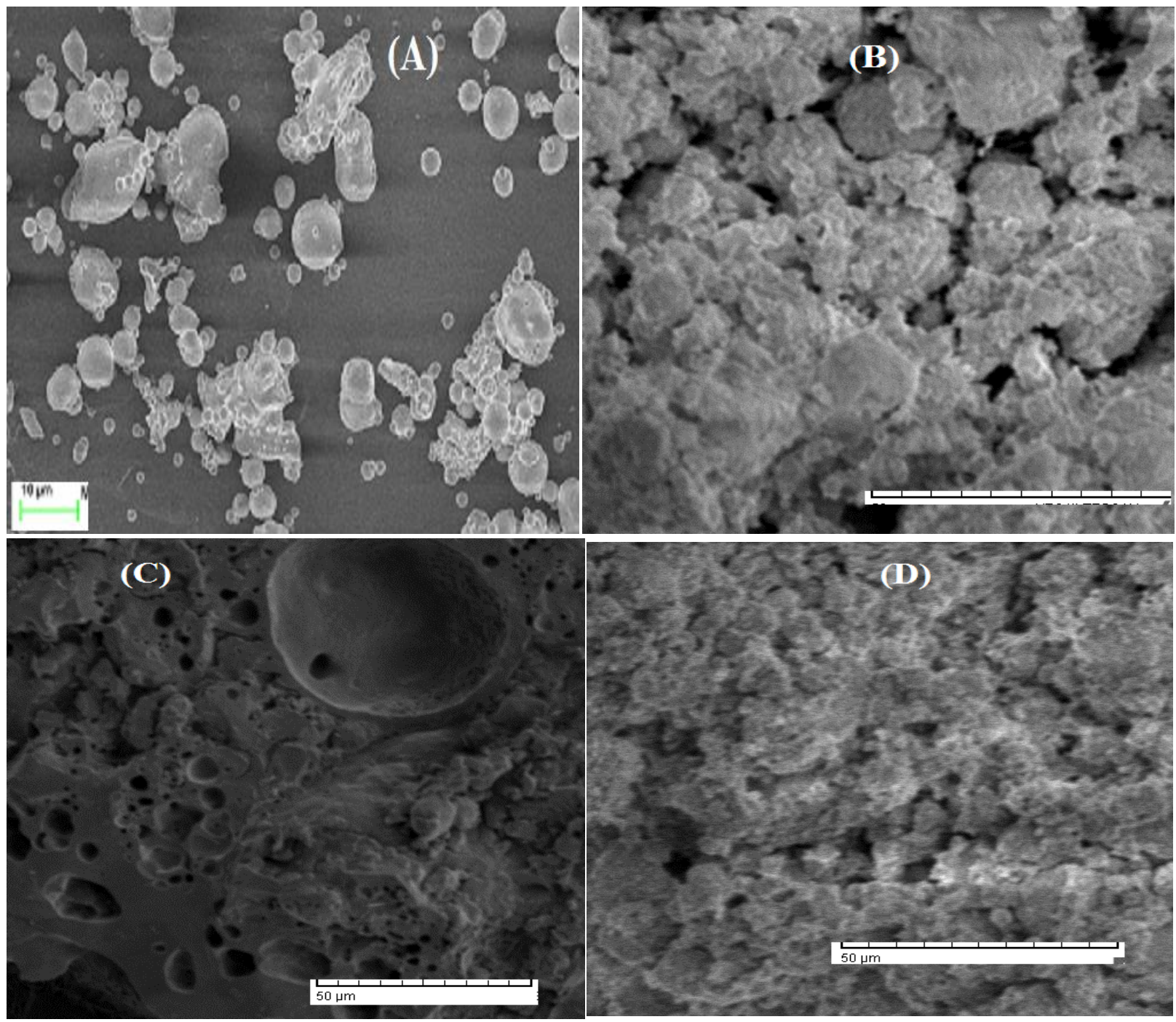

Figure 1 Morphological investigation of as-received fly ash (A), FA sintered at $900^{\circ} \mathrm{C}(\mathrm{B})$, FA sintered at $1100{ }^{\circ} \mathrm{C}(\mathrm{C})$, FA sintered at $1200^{\circ} \mathrm{C}(\mathrm{D})$ 

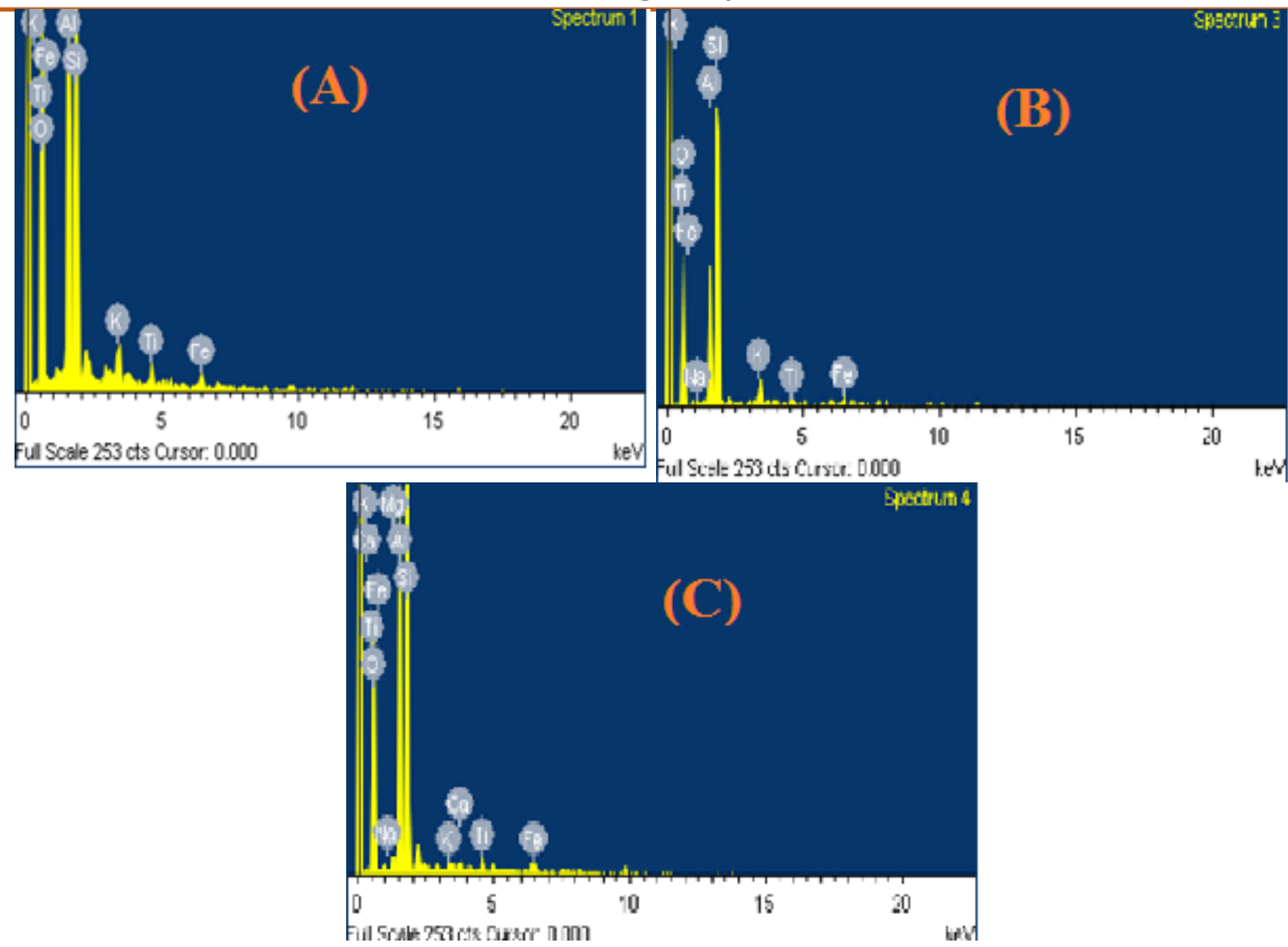

Figure 2 EDS spectrum of Fly Ash sintered at $900^{\circ} \mathrm{C}(\mathrm{A}), 1100^{\circ} \mathrm{C}(\mathrm{B}), 1200^{\circ} \mathrm{C}(\mathrm{C})$

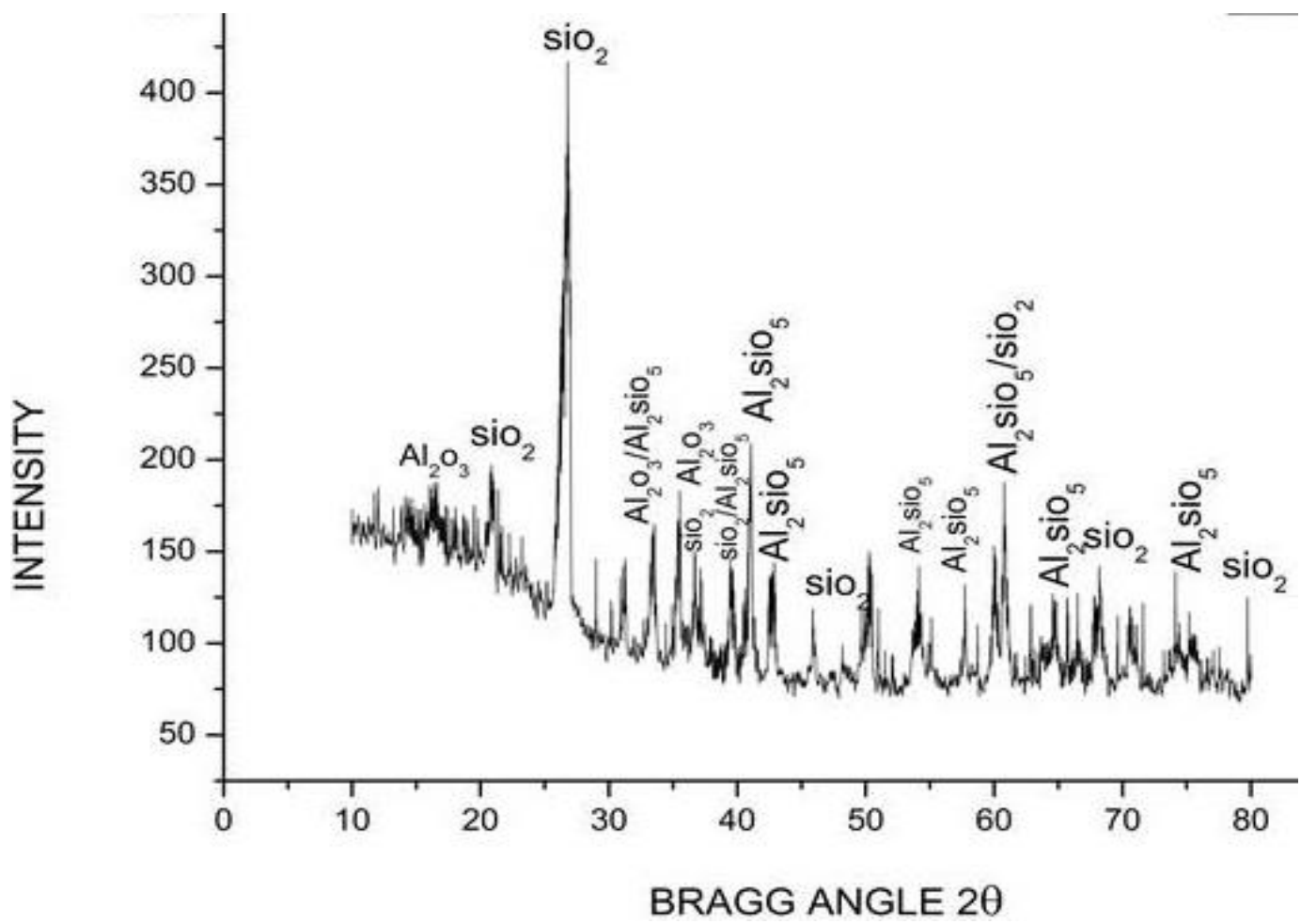

Figure 3 XRD analysis of as-received NALCO Fly Ash 


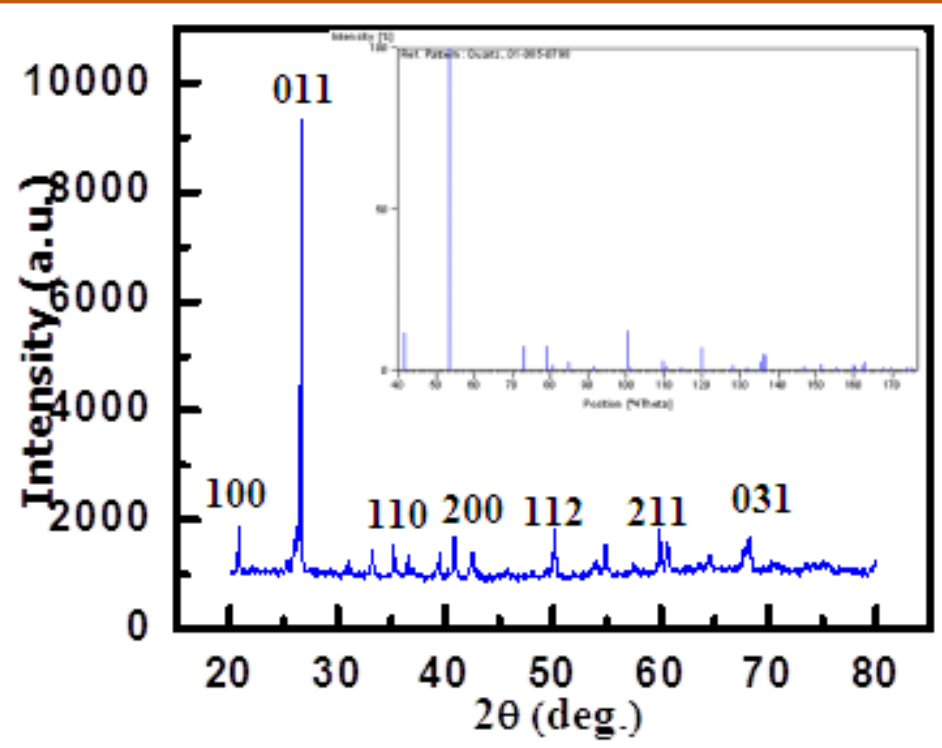

Figure 4 XRD pattern of Fly Ash sintered at $900{ }^{\circ} \mathrm{C}$ (Quartz Phase)

\begin{tabular}{|c|c|c|c|c|c|c|c|}
\hline \multicolumn{8}{|c|}{ Table 2} \\
\hline $\begin{array}{l}\text { Crystal } \\
\text { ID }\end{array}$ & $\begin{array}{l}\text { Mineral } \\
\text { name }\end{array}$ & $\begin{array}{l}\text { Crystal } \\
\text { system }\end{array}$ & $\begin{array}{l}\text { Space } \\
\text { group }\end{array}$ & $\begin{array}{c}\text { Space } \\
\text { group } \\
\text { number }\end{array}$ & $\begin{array}{c}\text { Cell } \\
\text { dimension }\end{array}$ & $\begin{array}{l}\text { Crystal } \\
\text { angle }\end{array}$ & $\begin{array}{c}\text { Calculated } \\
\text { density } \\
\left(\mathrm{g} / \mathrm{cm}^{3}\right)\end{array}$ \\
\hline $\begin{array}{l}\mathrm{FA}_{-} \\
900^{\circ} \mathrm{C}\end{array}$ & Quartz & Hexagonal & P3221 & 154 & $a=b \neq c$ & $\begin{array}{l}\alpha=\beta=90^{\circ} \\
\gamma=120^{\circ}\end{array}$ & 15.89 \\
\hline $\begin{array}{l}\mathrm{FA} \\
1100^{\circ} \mathrm{C}\end{array}$ & Mullite & Orthorhombic & Pbam & 55 & $a \neq b \neq c$ & $\alpha=\beta=\gamma=90^{\circ}$ & 3.17 \\
\hline $\begin{array}{l}\mathrm{FA} \\
1100^{\circ} \mathrm{C}\end{array}$ & $\begin{array}{l}\text { Terbium } \\
\text { Oxide }\end{array}$ & Cubic & 1213 & 199 & $a=b=c$ & $\alpha=\beta=\gamma=90^{\circ}$ & 7.89 \\
\hline $\begin{array}{l}\mathrm{FA}_{-} \\
1200^{\circ} \mathrm{C}\end{array}$ & Mullite & Orthorhombic & Pbam & 55 & $a \neq b \neq c$ & $\alpha=\beta=\gamma=90^{\circ}$ & 3.16 \\
\hline $\begin{array}{l}F A_{-} \\
1200^{\circ} \mathrm{C}\end{array}$ & Crystobalite & Tetragonal & P41212 & 92 & $a=b \neq c$ & $\alpha=\beta=\gamma=90^{\circ}$ & 2.26 \\
\hline
\end{tabular}

Figure 5 displays the line XRD parrten of mulite phase of processed Fly Ash, which is sintered at 1100 ${ }^{\circ} \mathrm{C}$. Table 2 specifies the crystal system and crystallographic parameters such as unit cell dimension, crystal angle, space group, space group number, and density of identified phases i.e., mulite phase. The highest intense peak is found at $53^{\circ}(2 \theta)$ in the line XRD parrten (Fig.5) and the phase is mulite (ICSD analysis). The other mulite phases are found at $33^{\circ}, 51^{\circ}, 61^{\circ}, 66^{\circ}, 70^{\circ}, 74^{\circ}$, and $78^{\circ}$, respectively in the Fig.5. The mulite phase belongs in orthorhombic crystal system. Crystallographic parameters are presented in Table 2. Other phases such as silica and alumina may present. Also, Glancing angle, d-spacing, and miller indices are indicated in Table 4.

Figure 6 displays the line XRD parrten of Terbium Oxide phase of processed Fly Ash, which is sintered at $1100{ }^{\circ} \mathrm{C}$. Table 2 specifies the crystal system and crystallographic parameters such as unit cell dimension, crystal angle, space group, space group number, and density of identified phases i.e.,
Terbium Oxide phase. The highest intense peak is found at $57^{\circ}(2 \theta)$ in the line XRD parrten (Fig.5) and the phase is Terbium Oxide (ICSD analysis). The other mulite phases are appeared at $40^{\circ}, 62^{\circ}$, and $71^{\circ}$, respectively in the Fig.6. The Terbium Oxide phase belongs in cubic crystal system. Crystallographic parameters are presented in Table 2. Table 5 impels glancing angle, $\mathrm{d}$-spacing and miller indices of sintered fly ash $\left(1100^{\circ} \mathrm{C}\right.$, Terbium Oxide Phase).

Figure 7 displays the XRD parrten of processed Fly Ash, which is sintered at $1200^{\circ} \mathrm{C}$. The highest intense peak is appeared at $22^{\circ}$ and it indicates the silica phase. Other peaks are assigned as other phases.

There is contained Line XRD pattern in Figure 7. The line parrten is analyzed of Mulite phase. Table 2 specifies the crystal system and crystallographic parameters such as unit cell dimension, crystal angle, space group, space group number, and density of identified phases i.e., mulite phase. The highest intense peak is found at $53^{\circ}(2 \theta)$ in the line XRD 
parrten (Fig.7) and the phase is mulite (ICSD analysis). The other mulite phases are appeared at $32^{\circ}, 46^{\circ}, 52^{\circ}$, $62^{\circ}, 66^{\circ}, 66^{\circ}, 70^{\circ}, 74^{\circ}$, and $78^{\circ}$, etc respectively in the Fig.7. The mulite phase belongs in orthorhombic crystal system. Crystallographic parameters are presented in Table 2.

Line XRD pattern is shown in Figure 8. The line parrten is analyzed of $\mathrm{SiO}_{2}$ phase. Table 2 specifies the crystal system and crystallographic parameters such as unit cell dimension, crystal angle, space group, space group number, and density of identified phases i.e., Crystobalite phase. The highest intense peak is found at $22^{\circ}(2 \theta)$ in the line XRD parrten (Fig.8) and the phase is Crystobalite (ICSD analysis). The other mulite phases are appeared at $56^{\circ}, 62^{\circ}$, and $72^{\circ}$, etc respectively in the Fig.8. The mulite phase belongs in Tetragonal crystal system. Crystallographic parameters are presented in Table 2. Glancing angle (2ロ), Miller indices, d-spacing are indicated Table 6.

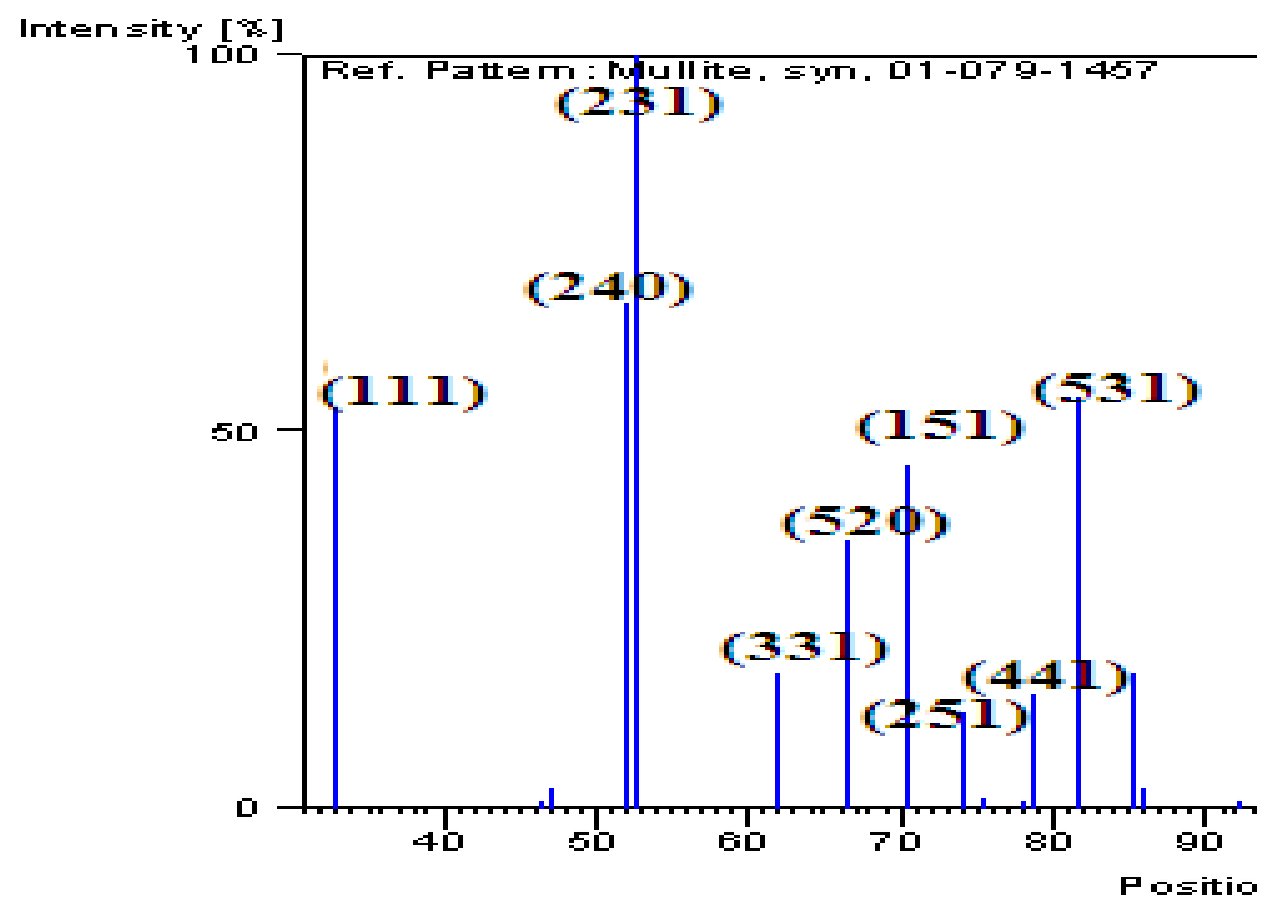

Figure 5 XRD pattern of Fly Ash sintered at $1100^{\circ} \mathrm{C}$ (Mulite Phase)

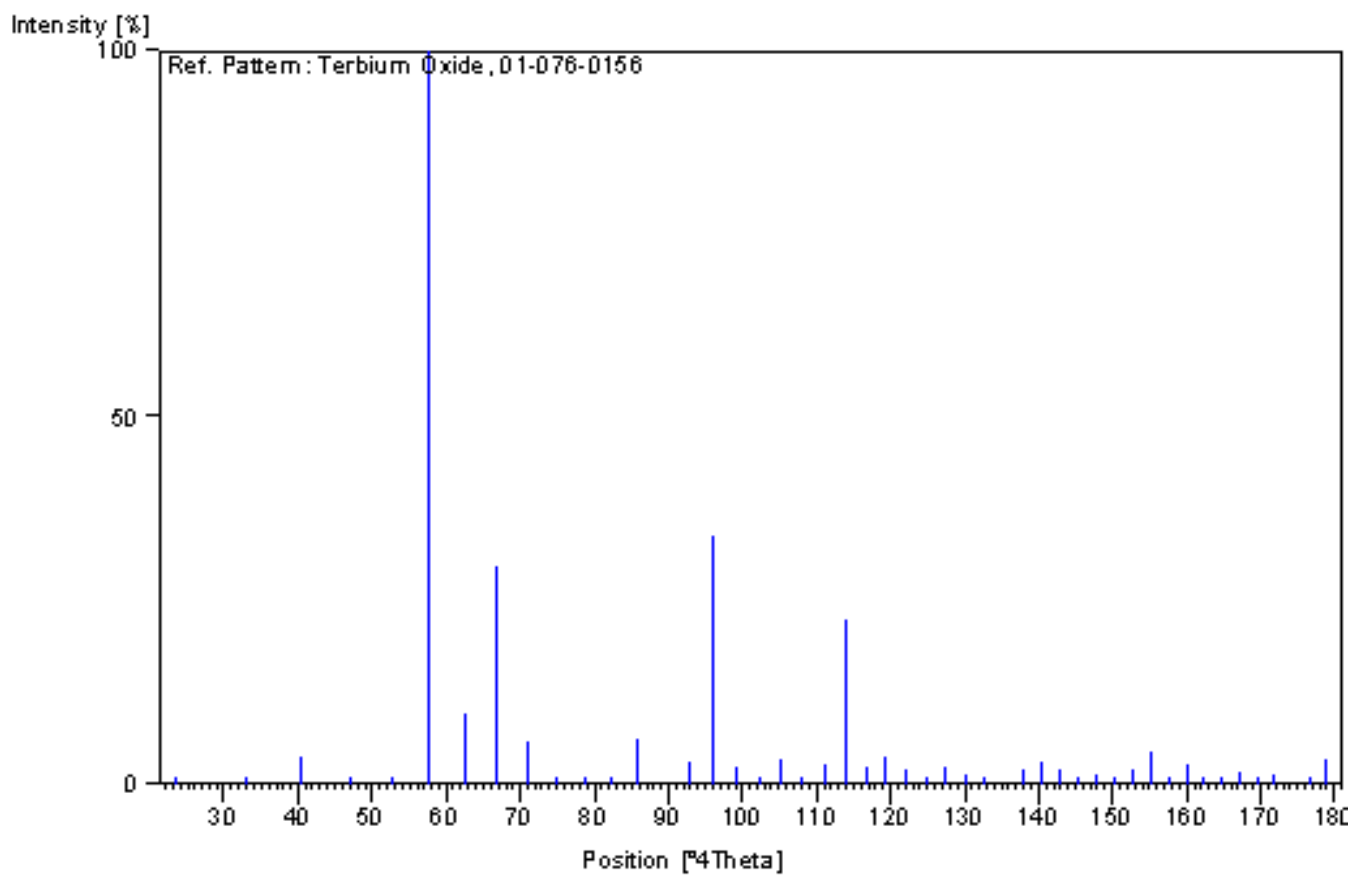

Figure 6 XRD pattern of Fly Ash sintered at $1100^{\circ} \mathrm{C}$ (Terbium Oxide Phase) 


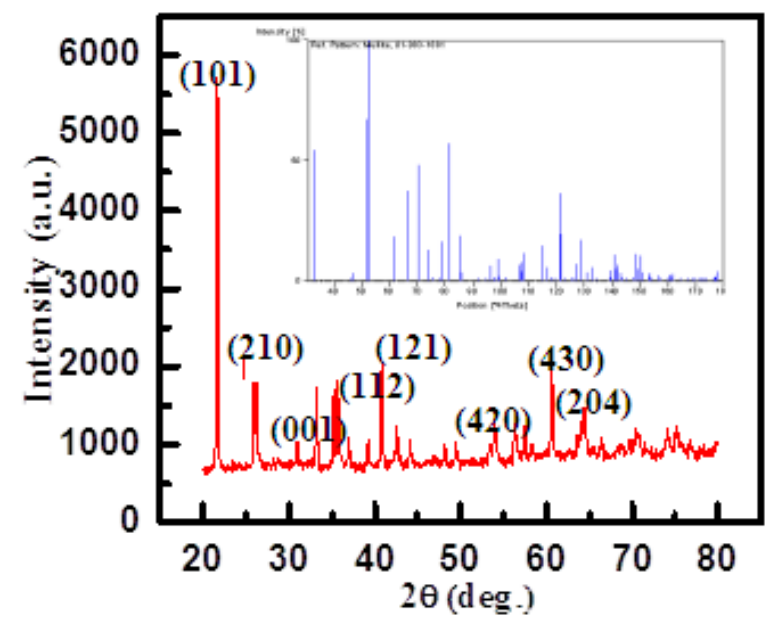

Figure 7 XRD pattern of Fly Ash sintered at $1200^{\circ} \mathrm{C}$ (Mulite Phase)

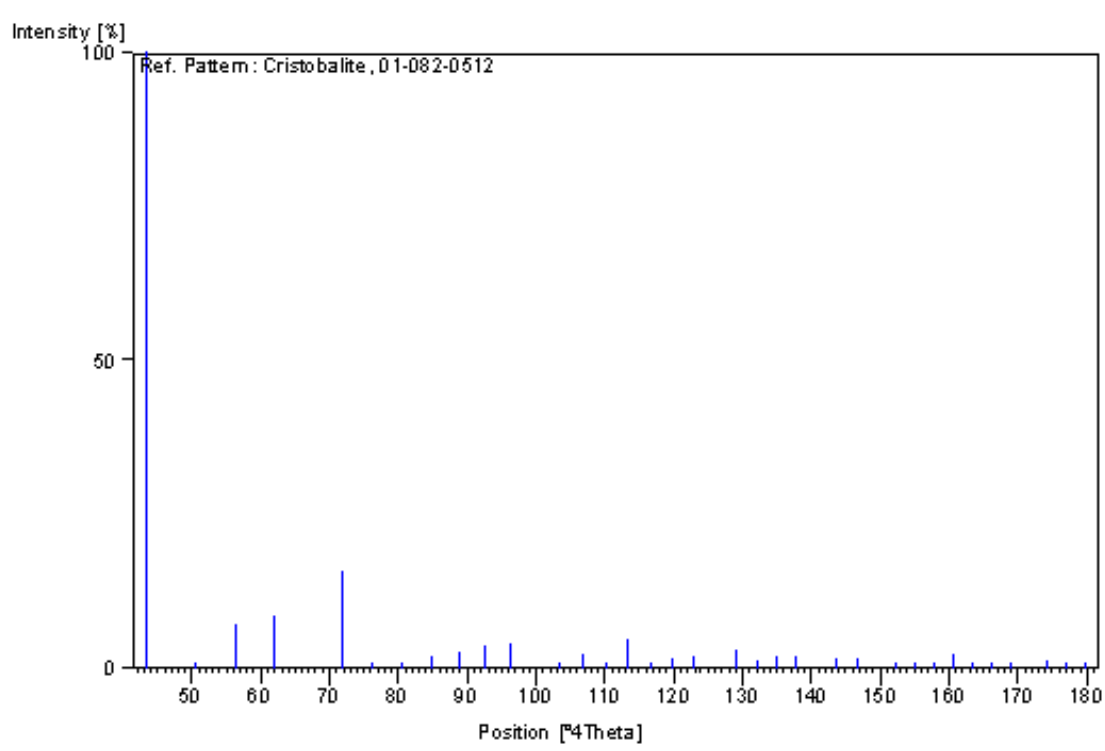

Figure 8 XRD pattern of Fly Ash sintered at $1200^{\circ} \mathrm{C}$ (Crystobalite Phase

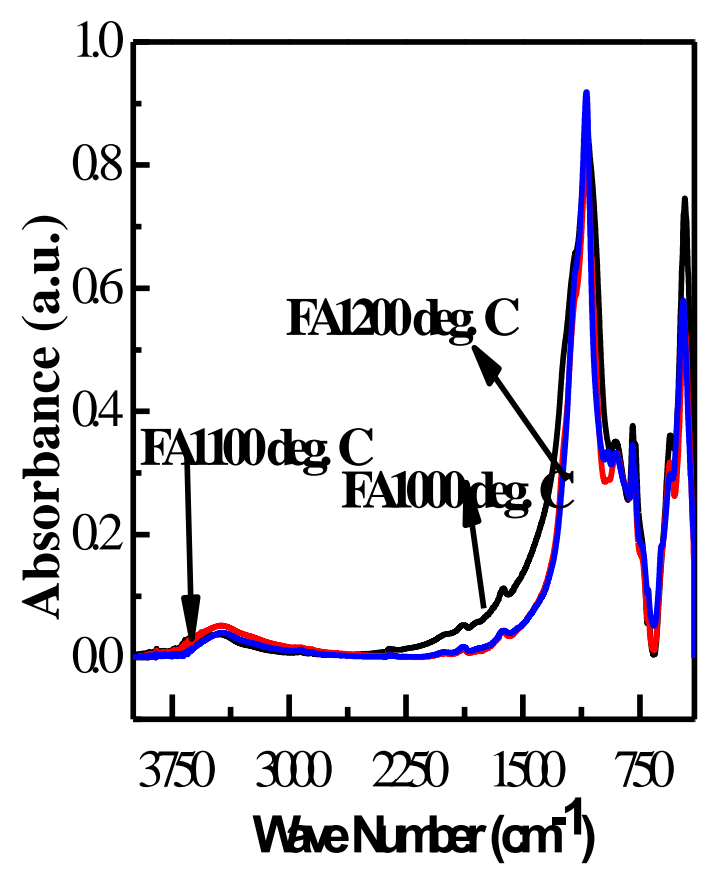

Figure 9 FTIR spectrum of sintered Fly ash at different temperatures $\left(1000^{\circ} \mathrm{C}, 1100^{\circ} \mathrm{C}\right.$, and $\left.1200^{\circ} \mathrm{C}\right)$ 
Table 8 Resistivity value of as-received fly ash and processed Fly Ash

\begin{tabular}{|l|l|l|l|l|}
\hline S. No. & Sample ID & Processing temperature $\left({ }^{\circ} \mathbf{C}\right)$ & Resistivity (MQ) & References \\
\hline 1 & Fly Ash & As received & 28.5 & {$[22]$} \\
\hline 2 & Processed Fly Ash & 900 & 28.7 & --- \\
\hline 3 & Processed Fly Ash & 1100 & 30.7 & --- \\
\hline 4 & Processed Fly Ash & 1200 & 35.1 & --- \\
\hline
\end{tabular}

FTIR absorption bands of as-processed NALCO fly ash is studied [22-24]. Presence of different absorption stretching frequency of Fly-ash powder corresponds to Fly-ash components. Stretching frequency at $600 \mathrm{~cm}^{-1}$ matches to Si-O-Al band [22]. Stretching frequency at 1098 and $1608 \mathrm{~cm}^{-1}$ is accredited to Si-O-Si asymmetric band [23] and $\mathrm{H}-\mathrm{O}$ $\mathrm{H}$, respectively.

Superimposed FTIR spectrum of the Fly ash based sintered materials (sintering temperature 1000 ${ }^{\circ} \mathrm{C}, 1100^{\circ} \mathrm{C}$, and $1200^{\circ} \mathrm{C}$ ) material is shown in Fig. 9 . Different peaks of the spectrum show the presence of different absorption bands of the sintered material. Fig. 9 shows the occurrence of various type absorption bands arising at different wave numbers i.e., 3441, 2918, 1823, 1638, 1117 and $907 \mathrm{~cm}^{-1}$. Stretching bands at $3441 \mathrm{~cm}^{-1}$ and $1638 \mathrm{~cm}^{-1}$ are indicate with vibrations of $\mathrm{O}-\mathrm{H}$ stretching bands and $\mathrm{H}-\mathrm{O}-\mathrm{H}$ bending band, respectively [23]. Absorption peak at $1117 \mathrm{~cm}^{-1}$ is indicated the $\mathrm{Si}-\mathrm{O}$ band and signifies the presence of silicate groups. $\mathrm{Al}^{3+} \mathrm{O}^{2-}$ absorption bands are also showed at $907 \mathrm{~cm}^{-1}$ [24].

The resistivity value of as-received fly ash and processed Fly Ash is presented in Table 8. From the resistivity data, the estimated highest resistivity is found to be $35.1 \mathrm{M} \Omega$ (for Fly ash processed at $900{ }^{\circ} \mathrm{C}$ ), whereas the lowest resistivity is found to be $28.5 \mathrm{M} \Omega$ (for as-received Fly ash). This is may be happened to the formation of more amounts mulite phases in the processed Fly Ash [22].

\section{Conclusions}

Sintered fly ash-based materials are successfully prepared through sintering process by solid state route. Different length of sintered temperatures such as $900{ }^{\circ} \mathrm{C}, 1000^{\circ} \mathrm{C}, 1100{ }^{\circ} \mathrm{C}$, and $1200{ }^{\circ} \mathrm{C}$ are used to prepare sintered samples. The structure and morphology of the materials are studied using XRD and FESEM characterization techniques, respectfully. The microstructure of as-received fly ash shows irregular spherical spheres, whereas different rate of compacted-shaped with crystalline phase are observed in sintered fly ash. Composed with microstructural analysis, ED's analyses show the presence of elements in the sintered materials. It indicates the existence of reaction during the sintering process. Different phases (mullite and quartz phases) are clearly observed in XRD pattern. The unit cell structure of mulite and quartz is orthorhombic and Tetragonal, respectively found at $1200{ }^{\circ} \mathrm{C}$. The estimated density of orthorhombic and tetragonal nit cell is $3.16 \mathrm{~g} / \mathrm{cm}^{3}$ and $2.26 \mathrm{~g} / \mathrm{cm}^{3}$, respectively. In FTIR spectra, there is observed a noticeable variance. The corresponding groups of the peaks are designated the formation of new bonds within the phases. The maximum electrical resistivity (Fly Ash processed at $1200^{\circ} \mathrm{C}$ ) is found to be $35.1 \mathrm{M} \Omega$.

\section{References}

[1] A. Tombak, J.P. Maria, F.T. Ayguavives, Z. Jin, G.T. Stauf, A.I. Kingon, A. Mortazawi, VoltageControlled RF Filters Employing Thin Film Barium-Strontium Titanate Tunable Capacitors, IEEE Transactions on Microwave Theory and Techniques, 51 (2) (2003) 462467. [DOl]

[2] B.J. Saikia, G.K Rao, P. Sarathy, Fourier Transform Infrared Spectroscopic Characterization of Kaolinite from Assam and Meghalaya, North Eastern India, Journal of Modern Physics, 1 (4) (2010), 206. [DOI]

[3] C.L. Goldsmith, A. Malczcwski, J.J. Yao, S. Chen, J. Ehmk, D.H. Hinzel, RFMEMS-Based Tunable Filters, International Journal of RF and Microwave Computer-Aided Engineering, 9 (4) (1999) 362.[DOl]

[4] D. Goski and M. Lambert, Engineering resilience with precast monolithic refractory articles, International Journal of Ceramic Engineering and Science, 1 (4) (2019) 169177. [DOl]

[5] E.C. Nzenwa, A.D. Adebayo, Analysis of Insulators for Distribution and Transmission Networks, American Journal of Engineering Research (AJER), 8 (2019) 138-145.

[6] F.H. Wee, F. Malek, S. Sreekantan, A.U. AlAmani, F. Ghani1, K.Y. You, Investigation of the Characteristics of Barium Strontium Titanate (BST) Dielectric Resonator Ceramic Loaded on Array Antennas, Progress in Electromagnetics Research, 121 (2011) 181213. [DOI] 
[7] G. Subramanyam, F.V. Keuls and F. A. Miranda, Novel K-band Tunable Microstrip vband Pass Filter using Thin Film HTS/Ferroelectric/Dielectric Multilayer Configuration, IEEE Microwave and Guided Wave Letters, 8 (2) (1998) 78-80. [DOl]

[8] H. E. Exner, E. Arzt, Sintering processes, Physical Metallurgy (Fourth, Revised and Enhanced Edition), 3 (1996) 2628-2662. [DOl]

[9] J. Nath, D. Ghosh, J.P. Maria, A.I. Kingon, W. Fathelbab, D. Paul, F.Z. Michael, B. Steer, An Electronically Tunable Microstrip Band Pass Filter using Thin-Film Barium-Strontium Titanate (BST) varactors, IEEE Transactions on Microwave Theory and Techniques, 53 (9) (2005) 2707. [DOI]

[10] L. Li and Y. Li, Development and trend of ceramic cutting tools from the perspective of mechanical processing, IOP Conference Series: Earth and Environmental Science, 94 (2017) 012062. [DOI]

[11] L. Wang, G. Hu, F. Lyu, T. Yue, H. Tang, H. Han, Y. Yang, R. Liu, W. Sun, Application of Red Mud in Wastewater treatment, Minerals, 9 (5) (2019) 281. [DOl]

[12] L.Y.V. Chen, R. Forse, D. Chase, R.A. York, Analog Tunable Matching Network using Integrated Thin-Film BST Capacitors, International Microwave Symposium Digest, 1 (2004) 261.

[13] M. Zhu, R. Ji, Z.Li, H. Wang, L.L.Liu, Z. Zhang, Preparation of glass ceramic foams for thermal insulation applications from coal fly ash and waste glass, Construction and Building Materials, 112 (2016) 398-405. [DOI]

[14] M. Ahmaruzzaman, A review on the Utilization of Fly Ash, Progress in Energy and Combustion Science, 36 (3) (2010) 327-363. [DOI]

[15] M.K. Panigrahi, Investigation of Structural, Morphological, Resistivity of Novel Electrical Insulator: Industrial Wastes, Bulletin of Scientific Research, 3 (1) (2021) 51-58. [DOl]

[16] M.K. Panigrahi, P. Kumar, B. Barik, D. Behera, S.K. Mohapatra, H. Jha, Frequency Dependency of Developed Dielectric Material from Fly Ash: An Industrial Waste, 20th National Conference on Nonferrous Minerals and Metals, 30 (2016) 143.

[17] N.S. Pandian, Fly Ash Characterization with Reference to Geotechnical Applications, Journal of the Indian Institute of Science, 84 (6) (2004) 189.

[18] N.S. Pandian, C. Rajasekhar, A. Sridharan, Studies of the Specific Gravity of Some Indian Coal Ashes, Journal of Testing and Evaluation, 26 (3) (1998) 177.
[19] R. Kulke, G. Mo"llenbeck, C. Günner, P. Uhlig, K.H. Drue, S. Humbla, J. Müller, R. Stephan, D. Sto"pel, J.F. Trabert, G. Vogt, M.A. Hein, A. Molke, T. Baras, A.F. Jacob, D. Schwanke, J. Pohlner, A. Schwarz, and G. Reppe, Ceramic Microwave Circuits for Satellite Communication, Journal of Microelectronics and Electronic Packaging, 6 (2009) 27-31. [DOI]

[20] R.P. dos Santos, J. Martins, C. Gadelha, B. Cavada, A.V. Albertini, F. Arruda, M. Vasconcelos, E. Teixeira, F. Alves, J.L. Filho, V. Freire, Coal Fly Ash Ceramics: Preparation, Characterization, and Use in the Hydrolysis of Sucrose, Scientific World Journal, 2014 (2014) 01. [DOI]

[21] S. Sushil, V.S. Batra, Catalytic Applications of Red Mud, an Aluminium Industry Waste: A Review, Applied Catalysis B: Environmental, 81 (1-2) (2008) 64. [DOl]

[22] T. Tanaka, Dielectric nanocomposites with insulating properties, IEEE Transactions on Dielectrics and Electrical Insulation, 12 (5) (2005) 914-928. [DOI]

[23] T. Tanaka, T. Imai, Advances in nanodielectric materials over the past 50 years, IEEE Electrical Insulation Magazine, 29 (1) (2013) 10-23. [DOI]

[24] W.V. Siemens, (1966) Inventor and entrepreneur: recollections of Werner von Siemens, Lund Humphries, London, England.

\section{Acknowledgement}

The author conveys their sincere thanks to GIET, Gunupur, Rayagada, Odisha, India for providing Lab facilities to do the research work. The author is also like to thank the CRF, IIT Kharagpur for their providing testing facilities.

\section{Funding}

No funding was received for conducting this study.

\section{Conflict of interest}

The Author has no conflicts of interest to declare that they are relevant to the content of this article.

\section{Does the Article Screened for Similarity?}

Yes.

\section{About the License}

(C) The Author 2022. The text of this article is open access and licensed under a Creative Commons Attribution 4.0 International License 